\title{
The Challenges of WTO Law: Strategies for Developing Country Adaptation
}

(forthcoming in World Trade Review, July 2006)

\author{
by Gregory Shaffer ${ }^{1}$
}

With the creation of the World Trade Organization ("WTO”), an area of international law may have become more like law as we commonly perceive it. Yet it is not necessarily the neutral technocratic process some of its proponents make it to be. Whatever is one's perspective on trade liberalization and its enforcement, developing countries and developing country constituents are at a disadvantage before the WTO's dispute settlement system. If the United States and European Community ("EC") have dozens of well-trained governmental lawyers and still frequently rely on assistance from private law firms, enterprises, and trade associations, how can developing countries manage?

Developing countries vary significantly in terms of the size of their economies and the role of law in their domestic systems. Nonetheless, they generally face three primary challenges if they are to participate effectively in the WTO dispute settlement system. These challenges are: (i) a relative lack of legal expertise in WTO law and the capacity to organize information concerning trade barriers and opportunities to challenge them; (ii) constrained financial resources, including for the hiring of outside legal counsel to effectively use the WTO legal system, which has become increasingly costly; and (iii) fear of political and economic pressure from members exercising market power, and in particular the United States and EC, undermining their ability to bring WTO claims. We can roughly categorize these challenges as constraints of legal knowledge, financial endowment, and political power, or, more simply, of law, money and politics. $^{2}$

This paper explores various strategies for responding to these three challenges, none of which involves a modification of the rules of the WTO's Understanding on Rules and Procedures Governing the Settlement of Disputes (the DSU), or of WTO jurisprudence. WTO members have been discussing an amendment of the DSU through a special negotiating session since 1997, but without reaching any consensus. ${ }^{3}$ This paper does not address the challenges posed by WTO

\footnotetext{
${ }^{1}$ Professor, University of Wisconsin Law School, Director UW European Union Center, Co-director UW Center on World Affairs and the Global Economy (WAGE).

${ }^{2}$ The author's focus on these three issues results from information provided in over one hundred interviews with key participants in, and observers of, the WTO dispute settlement system in Geneva, Switzerland, as well as in a number of national capitals. Those interviewed include representatives from over forty developed and developing country missions to the WTO, private lawyers and trade association representatives, over a dozen members of the WTO secretariat, six members of the Advisory Centre on WTO Law, and multiple representatives from the United Nations Conference on Trade and Development (UNCTAD) and other Geneva-based organizations. This information is still being processed. The author is preparing with other collaborators a survey of all WTO missions that will result in new data concerning their relative capacity to mobilize resources for WTO dispute settlement.

${ }^{3}$ In 1994, a Ministerial Decision sought a full review of the DSU by January 1, 1999. The DSB began informal "special sessions" in late 1997. After the DSB failed to reach consensus, the deadline was extended to July 1, 1999, but there was still no agreement at this time. (See WTO, "Understanding the WTO - The Doha Agenda," available at: http://www.wto.org/english/thewto_e/whatis_e/tif_e/doha1_e.htm.). At the Doha Ministerial Conference in
} 
dispute settlement rules themselves, such as the system's weak remedies which reduce the benefits of participation, nor does it address the impact of WTO jurisprudence on the costs of participation. These issues will be addressed in a separate study. ${ }^{4}$

In light of resource constraints, developing countries will obviously choose to dedicate more resources to other trade-related development initiatives than to WTO dispute settlement. Yet if the legal system is to work for them, they will need to examine cost-effective means to deploy it. While developing countries, and especially smaller ones, may not trade the volume or variety of products as large members, the trade barriers that they confront can often be of greater relative importance to their economies. That is, while they may have low absolute stakes in the trading system in relation to total world trade, they can have higher relative stakes in relation to their particular economies. ${ }^{5}$ There is thus a need to examine strategies for them to make better use of the current system

1. The Challenge of Internal Capacity: The Need for Bureaucratic and Public-Private Network Coordination. In order for a WTO member to use the WTO system successfully, it must develop cost-effective mechanisms to perceive injuries to its trading prospects, identify who is responsible, and mobilize resources to bring a legal claim or negotiate a favorable settlement. In the domestic socio-legal literature, these stages of dispute resolution are referred to as "naming, blaming and claiming." In the WTO context, a member's participation in the system will be, in part, a function of its ability to process knowledge of trade injuries, their causes, and their relation to WTO rights. Hiring lawyers to defend WTO claims is of little help if countries lack cost-effective mechanisms to identify and prioritize claims in the first place. Even where countries become aware of actionable injuries, this awareness will not be transformed into legal claims if, based on experience, officials lack confidence that a claim is worth pursuing in light of high litigation costs, weak remedies, and political risks.

2001, members agreed to continue the special session negotiations until May 2003. (See Doha Ministerial Declaration, WT/MIN(01)/DEC/1, adopted Nov. 14, 2001, para. 30.) This deadline was later extended to May 2004 by the General Council after the DSB acknowledged on July 24, 2003, that it needed more time to complete the DSU review. (See WTO, Dispute Settlement Gateway, at:

http://www.wto.org/english/tratop_e/dispu_e/dispu_e.htm\#dsb.) Yet, the deadline was extended once again on June 21, 2004, although no target date was set this time. (Dispute Settlement Body, Special Session of the Dispute Settlement Body, Report by the Chairman, Ambassador David Spencer, to the Trade Negotiations Committee, June 21, 2004.) As of 2005, negotiation of a new DSU still continues, since the special session is outside Doha's "Single Undertaking," which mandated the conclusion of all negotiations by Jan. 1, 2005. (See, e.g., "DSU Review:

Members Discuss Two New Contributions," Bridges Weekly Trade Digest, Vol. 9(7), March 2, 2005, available at: http://www.ictsd.org/weekly/05-03-02/story6.htm. See also "DSU Talks to Run Parallel to Doha Round to Provide More Momentum, Inside U.S. Trade 12 (March 18, 2005)).

${ }^{4}$ For a preliminary examination of the costs of WTO litigation in relation to its benefits, as well as a presentation of ideas of how WTO remedies could be modified in order to create incentives for greater developing country use of the system, see Gregory Shaffer, "How to Make the WTO Dispute Settlement System Work for Developing Countries: Some Proactive Developing Country Strategies” (ICTSD, Geneva) 1-65 (March 2003), at http://www.ictsd.org/pubs/ictsd_series/resource_papers/DSU_2003.pdf.

${ }^{5}$ For a development of this point, see id.

${ }^{6}$ See William Felstiner et al., The Emergence and Transformation of Disputes: Naming, Blaming and Claiming, 15 LAW \& SOC’Y REV. 631 (1980-81). 
The United States and EC have developed formal and informal legal mechanisms to identify foreign trade barriers, to prioritize them according to their impact, and to mobilize resources for WTO complaints. ${ }^{7}$ They have mobilized resources through interagency coordination and networking with the private sector, which, in turn, has engaged private law firms. Although many of the larger developing countries have taken significant steps in this direction, all developing countries face considerable internal bureaucratic hurdles. These hurdles include a bureaucratic tradition of foreign affairs ministries assuming the lead on trade dispute matters in which they have limited background; a lack of support from home capitals; a lack of financial and informational support from the private sector; a lack of legal expertise; and language barriers. ${ }^{8}$

In contrast to the United States and EC, developing countries have traditionally tended to assign a lower importance to trade matters within governmental hierarchies. ${ }^{9}$ While the United States Trade Representative (USTR) and the EC Trade Commissioner hold cabinet level positions, most developing countries do not assign a cabinet position for international trade matters. As a result, many developing countries still have a single diplomatic mission for handling matters before the WTO and the United Nations (UN) in Geneva. The mission is led by an official from the foreign affairs ministry since, generally, individuals from that ministry alone may hold the rank of ambassador. Even where a country has created a separate "head of mission" for WTO matters from a department that specializes in trade, such individual generally holds a lower level position in the government hierarchy.

This organizational choice does not mean that trade is invariably given little importance within the foreign ministry. For example, Brazil's past two ambassadors to the WTO (Celso Lafer and Celso de Amorim) became the country's foreign minister immediately following their Geneva posting. These assignments have provided Brazil's mission in Geneva with key support in the capital. In many cases, however, the assignment of WTO representation to the foreign affairs ministry indicates that WTO matters are viewed as traditional diplomatic ones, involving a traditional rotation of personnel to different geographic locations to handle different subject matter as part of a broad-based career path.

Studies of representation in international organizations have found that, "besides the representatives from the key member states [such as the US], the attribute most widely shared among the more influential actors in ... international organizations... was long association with the organization." ${ }^{10}$ Yet the career advancement of most developing country representatives in Geneva does not depend on their competence in technical WTO matters, and importantly for our purposes, in trade dispute settlement. Trade dispute settlement is incredibly time-consuming, and

\footnotetext{
${ }^{7}$ See Gregory Shaffer, Defending Interests: Public-Private Partnerships in WTO Litigation (2003).

${ }^{8}$ Similarly, in their review of the Argentine system, two Argentine scholars conclude: "In terms of domestic institutional setting, the lack of clear and pre-established mechanisms to handle disputes is detrimental to all actors. One feasible cost-effective solution would be to reallocate public officials to create a permanent and multidisciplinary corps of experts to handle trade disputes.” Diana Tussie and Valentina Tussie, "The Political Economy of Dispute Settlement: A Case from Argentina” 13 (August 2004) (paper on file with author).

${ }^{9}$ Interviews in Geneva with a wide range of developing country delegates.

${ }^{10}$ Robert Cox and Harold Jacobson, The Anatomy of Influence: Decision-Making in International Organizations (1974), at 395.
} 
as noted by two South American analysts, "out of the range of those who decide promotions within the Ministry [of Foreign Affairs]."11 Diplomatic success traditionally is not measured in terms of successful international litigation. Moreover, as a result of the diplomatic rotation system, a country's WTO unit in Geneva can suffer from a severe lack of continuity. By the time a replacement becomes versed in WTO matters, the delegate will move onto an unrelated post. ${ }^{12}$ These career incentives undermine a country's defense of its trading interests. These bureaucratic traditions can be difficult to change, especially where high level officials in the country's foreign ministry would feel threatened by change.

Developing country missions, in addition, suffer from a lack of support from national capitals. In light of the considerable complexity of WTO rules and of the WTO institutional structure, a developing country delegate cannot possibly follow all WTO developments. It has been estimated that there are over seventy different WTO councils, committees, working parties, and other groupings, involving over 2,800 meetings each year. ${ }^{13}$ Unlike the US and EC, most developing countries cannot afford to fly in officials from the capital for specific WTO meetings. Developing country delegates often receive little support at all. One former delegate of a developing country confirmed, "During the entire duration of the Uruguay round, our Genevabased WTO team received two instructions from our capital." ${ }^{14}$ Interviewed developing country diplomats generally admit that they would benefit from much greater organizational support from home.

The lack of bureaucratic coordination on trade matters can undermine Geneva-based representatives who might otherwise be more active in dispute settlement. Many developing countries require the approval of the attorney general's office in order to file a claim or a third party submission in a WTO case. This process can involve a complex exchange of formal letters between multiple ministries in the home country. These ministries can be subject to external

${ }^{11}$ Diana Tussie and Valentina Tussie, “The Political Economy of Dispute Settlement: A Case from Argentina” 9 (August 2004) (paper on file with author).

12 This tendency was repeatedly confirmed to the author in interviews with developing country representatives.

13 See Gary Sampson, Trade, Environment and the WTO: The Post-Seattle Agenda 24 (2000). As Sampson, the former Director of the WTO's Trade and Environment Division, notes, the Egyptian delegation to the WTO has estimated that there were 2,847 meetings in the WTO in 1997, or an average of 10 meetings per working day. (citing Communication from Egypt, High Level Symposium on Trade and Development, mimeo WTO 17 March 1997). Id. at 30. In consequence, many countries' representatives simply do not attend or keep up with developments in most WTO committees. Developing countries may lack the capacity to attend meetings in Geneva scheduled for their express benefit. As reported by a WTO official interviewed by Braithwaite and Drahos, "We set up a Subcommittee with a Chair and a Secretary who turned up for the first meeting on trade needs of LDCs [least developed countries]. No LDCs came. No developed countries came. No one came. Not one country showed up. If it had been telecoms, the chamber would have been packed [with special interests and states pushed by telecom interests].” John Braithwaite and Peter Drahos, Global Business Regulation 196 (2000). Many WTO members do not even maintain permanent offices in Geneva because of a lack of resources, and others have a staff of only a few people for all WTO and Geneva-based UN matters. As of May 2004, twenty-four WTO members and nine WTO observers did not have permanent missions in Geneva. See http://www.wto.org/english/tratop_e/devel_e/genwk_e.htm (visited May 10, 2005). See also “WTO organizes Geneva Week for non-resident delegations,” 43 WTO Focus 16 (Nov. 1999) (noting that twenty-eight did not have offices in Geneva in November 1999).

${ }^{14}$ Cited in Michel Kostecki, Technical Assistance Services in Trade-Policy, ICTSD Resource Paper No. 2 (Nov. 2001), at 9 . 
pressure, especially when the United States or EC is a party to a dispute. Such pressure, even if it does not induce a developing country to refrain from joining a complaint, can create so much delay that the Geneva-based official is unable to participate effectively. By the time the Genevabased representative receives the requisite government approval for the country to participate as a party or third party, the deadline for submissions may have passed. As a consultant who assisted sub-Saharan African countries notes:

"In most developing countries, particularly those in Africa, all government litigation has to be authorized or undertaken by the offices of the Attorney General (this is functionally more analogous to the US Solicitor General than the Attorney General). Without such clearance, no proceedings can commence. Typically therefore there has to be a complex exchange of letters (literally) between the Ministry of Trade (Geneva office sends this to the Minister in Capital who then endorses and sends to), the Attorney General's office, (that then has to liaise with) the Ministry of Foreign Affairs (for consistency with foreign policy).... The result is that there is extreme delay in delivering instructions to Geneva to proceed, which often is after the deadline." 15

Because of lack of support from home, Geneva-based representatives may become discouraged, reducing their incentive to participate in the dispute settlement system. If a major trade dispute subsequently arises in which the country is on the defensive, the mission may be utterly lacking in dispute settlement experience.

Many developing country missions suffer from a lack of national legal expertise in WTO matters, both within government and in the private bar. Diplomatic postings have generally been filled by non-lawyers. ${ }^{16}$ Most developing countries have only one or two lawyers (if any) to address WTO matters, whether in Geneva or in the home capital. As a representative from a Southeast Asian member stated, "I am the only lawyer here. I handle all DSU matters, as well as matters before other WTO committees." ${ }^{17}$ There may, moreover, be few (or no) private lawyers in the country knowledgeable about WTO law. WTO law, as opposed to traditional "public international law," has not traditionally been taught in developing countries, although this is changing in some countries. Many developing countries have, as a result, become dependent on education at law schools in the United States and Europe to develop local talent, provided that talent returns home. ${ }^{18}$

\footnotetext{
${ }^{15}$ E-mail from an individual who had provided assistance in such a case, Jan. 21, 2003.

${ }^{16}$ Of course, there are situations where non-lawyers master WTO legal matters, as is the case with the head of Brazil's unit for WTO dispute settlement. However, it is unlikely that this situation is common.

${ }^{17}$ DSU refers to the WTO “Dispute Settlement Understanding.” Interview with official, in Geneva, Switz. (Sept. 2002).

${ }^{18}$ Confirmed in interviews with developing country representatives in Geneva, Switz. (Sept. 2002, February and June 2003).
} 
Finally, most developing country officials must work in a foreign language in WTO judicial proceedings within this "Anglophone organization."19 Although English, French and Spanish are the three official languages of the WTO, English predominates. Even French and Spanish-speaking delegates are at a linguistic disadvantage. As an Argentine representative relates: "it is tiring and time consuming to wait for the translation in panel audiences. But also and perhaps more relevant, is that translation of documents may take 10 days and so it happens that panelists arrive to audiences without having had time to read them. This may be a disadvantage vis-á-vis documents submitted by the other part. Panelists have no clue of what our arguments are while they know the others', and this is a great disadvantage." ${ }^{20}$ The authors of an Argentine case study also note the value of English at panel hearings: "Sessions could be held in any official language, but after the initial presentations in Spanish led to yawning and dozing off by one member of the panel, a decision was taken to continue in English.,"21 Delegates speaking other languages are even worse off. To participate effectively, Thais, Malays and Indonesians, to give just three examples, would need to master the legal nuances of multiple three-hundred page WTO judicial decisions, often with limited legal training, and to do so in a foreign tongue.

Yet developing countries need to start somewhere. First, they can try to adapt from models used by larger developing countries for WTO dispute settlement, such as Brazil, which, in turn, have learned from US and EC models. As the United States, EC, and Brazil, developing countries can reorganize and better coordinate their ministries to target more resources at opening foreign markets for their exports. Some developing countries have created specialized trade bureaucracies or created specialized dispute settlement units within the foreign ministry. Some have attempted to adapt career paths to ensure greater continuity in WTO representation. A number of countries have included lawyers in their delegations. Many have developed closer relations with the private export sector. Brazil is arguably the most advanced developing country in this respect, having developed what it terms a "three pillar" structure involving a special WTO dispute settlement division in its capital Brasilia, coordination on WTO legal matters between Brazil's Geneva mission and this unit, and organized relations with the private sector. As part of this third pillar, the Brazilian government has helped facilitate the training of young attorneys in Brazilian law firms in WTO dispute settlement in the hope that they can help supplement constrained governmental resources. ${ }^{22}$ As one Brazilian representative notes, through creating

\footnotetext{
${ }^{19}$ Interview with Esperanza Duran, Director of the Agency for International Trade Information and Cooperation (AITIC), in Geneva, Switz. (June 20, 2002). AITIC works with least developed organizations from Francophone Africa.

${ }^{20}$ Interview cited in Tussie and Delich, "The Political Economy of Dispute Settlement: A Case from Argentina," at 10-11 supra note...

${ }^{21}$ Id., at 10.

${ }^{22}$ Interviews with Brazilian officials and private sector representatives in Sao Paulo, Brasilia, and Geneva, April and June 2004, as part of a project on the Brazilian model for WTO dispute settlement. Confirmed in presentation of Mr. Celso de Tarso Pereira, Brazil's legal representative at ICTSD’s seminar on WTO dispute settlement, Feb. 7, 2003 (Geneva).
} 
internships in Brazil’s mission in Geneva, "we are trying to spread knowledge of the system in order to create a critical mass."23

Second, developing countries could obtain more technical assistance from development agencies and foundations regarding opportunities for them to exercise their WTO rights. The WTO, UNCTAD, and the Advisory Centre on WTO Law are now providing training programs in WTO dispute settlement, which many officials have attended. ${ }^{24}$ Training in dispute settlement rules, however, is not sufficient. A central part of any dispute settlement process is the identification of potential legal claims-naming and blaming. As Hoekman and Kostecki write regarding WTO dispute settlement, "The Advisory Centre on WTO Law focuses only on the 'downstream' dimension of enforcement, not on the 'upstream' collection of information." 25 The European Commission realized that it lacked such information after the WTO system was established in 1995. It hired consultants to identify and report on sectoral trade barriers, which reports spurred a number of successful WTO complaints. ${ }^{26}$ Developing countries could request assistance from development agencies and foundations to help them identify trade barriers, broken down on a sectoral basis. UNCTAD and the World Bank jointly developed a software program named SMART (Software for Market Analysis and Restrictions on Trade) as a tool to assist developing countries during the Uruguay Round negotiations. The software permits countries to run a simulation of the trade effects of trade barriers so as to inform their negotiating strategies. $^{27}$ Similar systems could be developed for the purpose of WTO monitoring and enforcement. Hoekman has proposed that an "independent Special Prosecutor or Advocate" be mandated "to identify potential WTO violations on behalf of developing countries," which he terms an "outsourcing of discovery." Such a move would address "both the resource constraints

\footnotetext{
${ }^{23}$ Discussion with Brazil representative, Feb. 1, 2005, Geneva.

${ }^{24}$ On the WTO’s program, see Gregory Shaffer, "Can WTO Technical Assistance Serve Developing Countries," in Preparing the Doha Development Round: Challenges to the Legitimacy and Efficiency of the World Trading System, ed. Ernst-Ulrich Petersmann (Oxford University Press forthcoming 2005). On the Advisory Centre on WTO Law (ACWL) program, see its web site at http://www.acwl.ch/e/training/training_e.aspx (last visited May 10, 2005) (noting its six-month lunch-time training sessions on WTO dispute settlement procedures and jurisprudence for Geneva-based government officials from developing countries; and a new program for three nine-month internships for officials from least developed and other eligible ACWL members to join the ACWL staff as trainees). The fist two interns will be from Lesotho and Pargaguay. The United Nations Conference on Trade and Development (UNCTAD) has also created a program for WTO dispute settlement training. See Daniel Pruzin, "U.N. Agency Outlines Proposal for WTO Dispute Settlement Training,” 17 International Trade Reporter (BNA) 196 (Feb. 3, 2000). The above was confirmed in interviews with the Director of the ACWL and developing country delegations to the WTO in Geneva, July 2005.

${ }^{25}$ Hoeckman B. and M. Kostecki, The Political Economy of the World Trading System: the WTO and Beyond, (2nd edition), (Oxford University Press: 2001) pp. 94-95 (also noting that "One option to deal with the information problem is for the private sector to cooperate and to create mechanisms through which data on trade... barriers are collected and analyzed").

${ }^{26}$ See Shaffer, Defending Interests, supra note _.

${ }^{27}$ The software has been installed in a large number of developing countries. It has been incorporated into UNCTAD's TRAINS system (Trade Analysis and Information System). See http://r0.unctad.org/trains/. Compare Shaffer, Defending Interests, supra note _ , at 69-70 (concerning the EC's market access database).
} 
and the incentive problems (fear of cross-issue linkage) that may impede developing country governments from pursuing cases., ${ }^{28}$ These mechanisms could build on, and feed into, WTO reviews of countries' compliance with obligations under the Trade Policy Review Mechanism and through WTO oversight committees. They also could be developed on a regional basis through regional trade associations, possibly with the financial assistance of regional development organizations.

Such information, however, will only be of use if there is bottom-up demand for them. As Stephen Denning writes, "Organizations that focus completely on collecting information with little or no effort to foster people connections end up with repositories of dead documents." 29 Thus, most importantly, developing countries need to develop routinized relations with the private sector to identify trade barriers and investigate and prioritize them.

The private sector in developing countries, however, has typically viewed WTO dispute settlement as the government's job. This perspective can pose a serious problem for developing country trade officials who have fewer public resources than their US and EC counterparts, counterparts who have already developed mechanisms to work with their own private sectors. ${ }^{30}$ Developing country officials could strive to foster the development of a reflex within their export sectors to assist them in investigating claims and building factual and legal cases, just as the EC did following the WTO's creation. ${ }^{31}$ Developing countries would then have better access to the information necessary to enforce their trading rights through the dispute settlement system and through favorable settlement in its shadow. As Tussie and Delich conclude regarding their review of Argentina's work with the private sector in dispute settlement, "It would have been impossible to do the groundwork for the case [which involved Chilean duties on vegetable oils] without the provision of factual information, statistical data and financial collaboration from business." ${ }^{32}$ The development of public-private networks for trade litigation represents a more market-based instrument for challenging trade barriers, yet one that government action can facilitate. $^{33}$ Because private enterprises do not necessarily have the same interests as the government, public authorities will need to channel and steer these private resources toward public ends. Yet unless developing country public-private networks are formed, the resources may not be made available in the first place.

\footnotetext{
${ }^{28}$ See Bernard Hoekman, "Strengthening the Global Trade Architecture for Development," 1:1 World Trade Review, 1, 36 (2002).

${ }^{29}$ Stephen Denning, “Technical Cooperation and Knowledge Networks,” in eds. Sakiko Fukuda-Parr, Carlos Lopes and Khalid Malik, Capacity for Development: New Solutions to Old Problems (Stylus: 2002), p. 242.

${ }^{30}$ See Shaffer, Defending Interests, supra note _.

${ }^{31}$ See Shaffer, Defending Interests, supra note _ at 115 (citing Alistair Stewart, head of the Commission's market access unit: "the Commission would like a new reflex to be developed on [business's] part, and considers that this would be very much in their interest").

32 Diana Tussie and Valentina Tussie, “The Political Economy of Dispute Settlement: A Case from Argentina” 13 (August 2004) (paper on file with author).

${ }^{33}$ Compare US and EC governmental action to facilitate the development of public-private networks, in Shaffer, Defending Interests, supra note..., including at 113-117.
} 
2. The Financial Challenge: Subsidized Legal Assistance; Private Sector Support; Pooling Resources through Regional and International Legal Centers. A second major challenge that developing countries face is that they have fewer resources to spend on legal assistance to defend their WTO rights. Their government budgets are constrained, often compounded by debt obligations, and there are high opportunity costs to investing in WTO litigation as opposed to other social needs.

Compared to larger, wealthier members, developing countries face much higher relative and absolute costs in WTO litigation. First, the relative costs of litigation are much higher for them in relation to the size of their economies and government budgets. Investing in WTO legal expertise thus makes less sense for them in relation to other budgetary needs. Second, developing countries face higher absolute costs for an individual case. Since most developing countries participate less frequently in WTO dispute settlement, they do not benefit from economies of scale. The US and EC, for example, have respectively participated as a party or third party in around $98 \%$ and $86 \%$ of WTO cases that resulted in an adopted decision. ${ }^{34}$ Because of their prior and ongoing litigation experience, the US and EC face fewer start-up costs for an individual case. Put in other words, the US and EC can spread the "fixed costs" of developing internal legal expertise over more cases than developing countries. For a particular case, the US and EC expend primarily only the "variable costs" of preparation and litigation of that case. It is thus less cost-effective for developing countries to develop significant internal legal expertise to handle WTO complaints.

Developing countries' best alternative is thus either to work with private law firms, possibly funded by private enterprises, or with a subsidized legal services organization that is autonomous of the WTO, such as the Advisory Centre on WTO Law. Both private law firms and legal service organizations are more likely to be repeat players, representing multiple parties in WTO litigation over time. Private law firms and subsidized legal services organizations are thus able to develop legal expertise in a more cost-effective manner which they can deploy for a particular case.

Another alternative would be for the WTO secretariat or an independent organization to act as a public prosecutor, similar to the role that the European Commission assumes before the European Court of Justice within the EC's legal system. This alternative would expand on Hoekman's proposal, since the "special prosecutor" would not only identify claims but also litigate them, as done in the EC. However, this alternative appears to be politically infeasible at this time, especially in terms of actual litigation by a special prosecutor, because of challenges to WTO legitimacy (especially were the prosecutor linked to the WTO secretariat) and because the most powerful WTO members would not support it. Thus, the only alternatives appear to be subsidized legal assistance and use of private law firms. ${ }^{35}$

\footnotetext{
${ }^{34}$ This calculation is based on an update of Tables 6.1 and 7.1 of Shaffer, Defending Interests, supra note..., at 132 and 157 (noting 97\% and 81\% participation rates as of January 17, 2003).

${ }^{35}$ A complementary mechanism would be to reform remedies to provide for attorney fee awards or cash damages that would create incentives for entrepreneurial private law firms, but this would involve a change in DSU rules. Alternatively, WTO procedures could be simplified to reduce the costs of participation. Some mechanisms exist under the current system, but are not deployed. See Hakan Nordstrom, "The cost of WTO litigation, legal aid and small claim procedures" (March 2005 discussion paper on file with author) (noting articles 5 and 25 of the DSU on mediation and arbitration, subject to the parties' agreement; and the accelerated procedures of the Decision of 5
} 
In many cases, private companies and trade associations can pay for a private law firm that will work with the government in preparing a WTO case. Some larger developing countries have worked with the private sector to hire private law firms to assist in the bringing of complaints. Brazil worked with Sidley Austin Brown \& Wood for the cotton and sugar subsidies cases against the United States and EC. Thailand hired Lalive \& Partners in the US-shrimp-turtle case. Korea hired Marco Bronkers, now with Wilmer Cutler \& Pickering, in the Korea-alcohol case. Some smaller countries have followed suit, such as the Caribbean country of Antigua and Barbuda in its challenge to U.S. internet gambling restrictions, in which private lawyers from firms based in the United States and United Kingdom were hired by private companies to help represent the island nation. ${ }^{36}$ U.S. and European law firms actively promote their skills in Geneva, and are often seen in the WTO building for hearings or simply to make contact with former or potential clients.

Developing countries also have the opportunity to obtain partially subsidized legal assistance through the Advisory Centre on WTO Law in Geneva, an international legal services organization. ${ }^{37}$ The Agreement establishing the Advisory Centre on WTO Law was signed by twenty-nine countries on December 1, 1999 at the WTO Ministerial Meeting in Seattle, Washington, and it entered into force on July 15, 2001. With Costa Rica's plan to join the Advisory Centre in 2005, all developing countries and customs territories that have participated in WTO "proceedings [as a complainant or respondent] more than twice and fewer than 18 times will have joined the Centre."38 The Centre is funded largely by European governments, although developing country members (other than the least developed countries) must also pay a membership fee that is determined in relation to their per capita income and share of world trade. $^{39}$ In May 2005, the Centre consisted of eight lawyers, under the executive directorship of Frieder Roessler, former head of the legal affairs division of the GATT secretariat.

April 1966 (BISD 14S/18) for developing country complaints against developed countries, but the procedures only reduce the time for panel decisions in a situation where developing countries already have difficulty meeting time constraints).

${ }^{36}$ See Daniel Pruzin and Christopher Rugaber, "WTO Publishes Final Decision on Internet Gambling; U.S. to Appeal,” International Trade Reporter (BNA) vol 21: 46, at 1874 (Nov. 18, 2004).

37 See the web site of the Advisory Centre, on WTO Law, Welcome to the Advisory Centre on WTO Law, at http://www.acwl.ch/e/index_e.aspx (last visited May 8, 2005).

${ }^{38}$ ACWL, "Cost Rica to Join the Centre,” at http://www.acwl.ch/e/tools/news_detailsphoto_e.aspx?id=5b5103c553af-4273-a95e-1d0e75d003ec (visited May 10, 2005).

39 See Advisory Ctr. WTO Law, Report on Operations: July 2001-June 2002 available at www.acwl.ch), at 8. Because of the membership fee, a developing country (other than a least developed country) may wait to join the Centre until it believes that it can benefit meaningfully from WTO litigation. The United States is not a member of the Centre and provides no funding for this initiative. Canada is the only non-European developed country member of the Centre. The other nine are Denmark, Finland, Ireland, Italy, Netherlands, Norway, Sweden, Switzerland and the United Kingdom. The term "least developed country" is clearly defined according to United Nations criteria based on per capita income and related development indicators. The criteria used in the triennial review in 2003 were based on domestic gross domestic product (under $\$ 900$ average over three years), a human resource weakness index and an economic vulnerability index. See UN, "The Criteria for the Identification of the LDCs," at http://www.un.org/special-rep/ohrlls/ldc/ldc\%20criteria.htm (last visited May 8, 2005). There were fifty countries listed as LDCs, as of May 8, 2005. Id. 
The Advisory Centre is designed to counsel and represent developing countries so that they may defend their WTO rights at less-than-market rates that vary depending on the country's membership status, share of world trade, and per capita income. ${ }^{40}$ By May 2005, the Advisory Centre had represented eight developing countries (Ecuador, Honduras, India, Indonesia, Pakistan, Paraguay, Peru, and Thailand) in twelve WTO cases, in addition to assisting countries in the "consultation phase" of disputes and providing consulting advice in respect of potential claims. ${ }^{41}$ As a repeat player in WTO litigation, the Advisory Centre can provide legal services to developing countries in a manner somewhat analogous to the way in which the European Commission's Legal Services assists EC member states in WTO litigation. By pooling their resources, European countries have enhanced their voice and collective knowledge of WTO law in a cost-effective manner. ${ }^{42}$ Small European countries, such as Portugal and Ireland and now most Eastern European countries, may rely on the Commission as a repeat player in WTO litigation. They are thereby able to participate more effectively in the defense of their interests and in the overall shaping of WTO law through the judicial process. The Advisory Centre, although it will operate in a more ad hoc manner for developing countries, can similarly develop a reservoir of WTO expertise into which developing countries can tap. It can thus more effectively provide developing country input into the judicial construction of the law over time.

Developing countries could use the Advisory Centre in different ways, depending on their level of development and the frequency with which they participate in WTO disputes. Larger, more active countries, such as India, may use the Centre to develop their own national expertise in WTO dispute settlement. ${ }^{43}$ Smaller countries that rarely engage in WTO disputes may find it less cost-effective to develop their own legal expertise and thus almost solely rely on the Centre, as did Peru in its case against the EC concerning whether its fish species could be sold in the EC as sardines. ${ }^{44}$ Yet even larger developing countries, such as India, will find that

40 Under the annexes to the agreement establishing the Centre, developing countries are divided into three categories, A, B and C, with least developed countries (as defined by UN rules) constituting a fourth category. As of August 2002, hourly rates for the Centre’s members for WTO litigation support were set at \$200 for category A countries, $\$ 150$ for category B countries and $\$ 100$ for category C countries. Least developed countries hourly rates are set at $\$ 25$. Non-member developing country rates are set at $\$ 350$ for category A countries, $\$ 300$ for category B countries, and \$250 for category C countries. See The Agreement Establishing the Advisory Centre on WTO Law, Annex II, Nov. 13, 1999, available at http://www.acwl.ch/Docs/ACWLAgreementEnglish.htm.

41 See listing at http://www.acwl.ch/e/dispute/wto_e.aspx. See also e-mail from the Advisory Centre in November 2004 (on file). The first seven cases involved India (three cases), Pakistan, Peru, and Ecuador. Ecuador's case against Turkey was settled. See Report on Operations, supra note _, at 81-84.

${ }^{42}$ Most WTO expertise in Europe now resides within the European Commission, and not in individual member state trade administrations. See Shaffer, Defending Interests, supra note _.

43 The Centre is also provides internship possibilities and organizes weekly and other periodic seminars for developing country officials. See http://www.acwl.ch/e/training/training e.aspx.

${ }^{44}$ Interview with Peruvian official, in Geneva, Switz. (June 21, 2002). See Gregory Shaffer \& Victor Mosoti, "ECSardines: A New Model for Collaboration in Dispute Settlement,” Bridges (ICTSD) 15 (Oct. 2002). Nonetheless, 
the Advisory Centre can provide an important complement to their domestic resources. Just as the EC has sometimes farmed out WTO cases to private law firms, and just as the USTR and the EC have collaborated with private counsel hired by private firms, so the Centre can be of assistance to even the most sophisticated developing country trade administration. In addition, private enterprises could (indirectly) pay the Centre's fees or hire a law firm to work with the Centre's lawyers. Such collaboration occurred in the WTO case involving EC export subsidies for sugar, when a U.S. law firm represented Brazil and the Centre represented Thailand as a cocomplainant. ${ }^{45}$ The Centre, as all participants in WTO litigation, has encountered major challenges in light of WTO jurisprudential developments that require intensive fact-gathering and rely less on presumptions and references to general principles. ${ }^{46}$ Yet the Centre is better able to adapt to WTO jurisprudence than individual developing countries.

The Advisory Centre could also assist groups of like-minded developing countries in preparing third party submissions in WTO disputes to defend their systemic interests. In light of the weakness of the current WTO political system and the resulting importance of individual WTO cases for the interpretation of WTO law, developing countries should consider organizing on a more consistent basis to present their views as third parties. Only the United States and EC participate routinely as third parties in cases where they are not a plaintiff or defendant. ${ }^{47}$ They do so especially before the Appellate Body where participation has the greatest systemic impact. By preparing joint third party submissions, the Advisory Centre could place dispute settlement panels and the Appellate Body on notice of the views of organized groups of developing countries in individual cases. Yet the Advisory Centre has never represented a group of developing countries as third parties. ${ }^{48}$

In addition, developing countries may wish to seek funding for legal support centers in Washington and Brussels to complement the Advisory Centre. Much of the legal action for market access takes place before U.S. and EC administrative bodies, in particular in antidumping, subsidy, and safeguard cases. These cases can be extremely expensive, so expensive that many developing country enterprises simply cease exporting to the United States or Europe upon the initiation of a complaint. Statistical evidence reveals that lower income developing countries fare far worse in U.S. antidumping proceedings than do developed country defendants. They "are more likely to be targeted, less likely to settle cases, more likely to confront high dumping duties and less likely to bring cases to the WTO."49 Developing a legal

\footnotetext{
“delegates of Peru have attended the lunch-time [ACWL] training sessions in all three years.” The author thanks an anonymous referee for this point.

${ }^{45}$ Discussion with member of the Advisory Centre, November 2004.

${ }^{46}$ See e.g., US-Rules of Origin for Textiles and Apparel Products, in which the Centre unsuccessfully represented India. Some governments may retain private counsel themselves, instead of the Advisory Centre, in light of their determination of the case's relative importance, private counsel's reputation and cost-effectiveness, and the country's past experience. Interview with delegates from Brazil and Chile, among other WTO missions, Geneva, June 2003 and 2004.

${ }^{47}$ Japan has also been a frequent third party. See Shaffer, Defending Interests, supra note..., at 157.

${ }^{48}$ Confirmed by Leo Palme of the Advisory Centre, Feb. 1, 2005.

${ }^{49}$ See Chad Bown, Bernard Bernard Hoekman \& Caglar Ozden, "The Pattern of US Antidumping: The Path from Initial Filing to WTO Dispute.” 2:3 World Trade Review 349-371 (November 2003).
} 
resource center in Washington and Brussels to provide developing countries with partially subsidized legal support may be difficult, but that does not detract from its importance. One possibility could be to tie such a center to a law school, similar to the way in which the Center for International Environmental Law (CIEL) "directs a joint research and teaching program with the American University Washington College of Law” in Washington D.C.. As CIEL's web site note, the program includes "on-the-job experience through an extensive internship program... [whose] participants are drawn from the Washington College of Law’s Master of Laws program which each year enrolls 180 foreign lawyers from 60 countries from around the world."50 This initiative could be easier to accomplish in the United States in light of US law schools' experience with clinical programs that provide course credit, although analogous mechanisms could be explored in Brussels.

WTO cases increasingly involve challenges to U.S. and EC trade remedy procedures. ${ }^{51}$ In mid-2004, trade remedy cases comprised slightly over one-half of the twenty-three active panel and Appellate Body proceedings. ${ }^{52}$ The U.S. and EC were respectively the two major targets. In these cases, the Appellate Body has sometimes refrained from finding that U.S. and European import relief laws themselves violate WTO obligations, and rather held against U.S. and European administrative practices. ${ }^{53}$ Developing countries must thus develop a factual and legal record in the U.S. and EC domestic proceeding if they are to successfully pursue a matter before the WTO.

Parties also need to ensure that U.S. and European administrative bodies take account of WTO jurisprudence in applying domestic law. Although WTO law has no direct effect in the United States or Europe, domestic administrative bodies and courts should take account of WTO law in interpreting the relevant domestic statutes on the ground that the statutes were intended to implement WTO law. The European Court of Justice has expressly maintained that it will interpret EC law to conform, where possible, with EC obligations under WTO agreements. ${ }^{54}$

${ }^{50}$ The quotation is from CIEL's home page at http://www.ciel.org/reciel.html (last visited Feb. 15, 2005).

${ }^{51}$ From the WTO's formation through September 2001, WTO members filed eighteen complaints against the United States in respect of its antidumping and countervailing duty laws and six additional complaints against U.S. application of its import safeguards law. During the first nine months of 2001 alone, WTO members filed seven new requests for consultations and panel formations in respect of U.S. antidumping and countervailing duty laws and measures. In a three week period at the end of the summer of 2001, WTO panels were formed to hear challenges on four separate challenges against U.S. import protection laws and proceedings. See, e.g., "U.S. Peppered with WTO Complaints, Criticizes Prior Rulings,” 19 Inside U.S. Trade 6 (Aug. 24, 2001).

${ }^{52}$ See Rossella Brevetti, "Fewer WTO Cases Filed So Far in 2004, Legal Affairs Director Wilson Says," International Trade Reporter (BNA), vol 21: 34, at 1378 (Aug. 19, 2004) ("Wilson said that 53 percent are trade remedy cases and 47 percent are non-trade remedy cases").

${ }^{53}$ See, e.g., Report of the Appellate Body, United States-Countervailing Measures Concerning Certain Products from the European Communities, WT/DS212/AB/R (Nov. 22, 2002), para. 161 (reversing the panel's decision that certain provisions of U.S. countervailing duty law did not conform with the United States' obligations under the SCM Agreement, but upholding the panel's decision that the U.S. administrative determinations were made in a manner "inconsistent" with the SCM Agreement, and "requesting" the United States to bring its "administrative practice... into conformity with its [WTO] obligations").

${ }^{54}$ See e.g. Case C-53/96, Hermes Int’l v FHT Mktg. Choice BV, 1998 ECR I-3603 (1998). 
There is likewise long-standing U.S. Supreme Court precedent that "an Act of Congress ought never to be construed to violate the law of nations, if any other possible construction remains." 55 This jurisprudence was cited with approval in the U.S. domestic litigation following the Appellate Body's U.S.-shrimp-turtle decision. The U.S. Court of Appeals for the Federal Circuit overruled the lower court and interpreted the U.S. statute in conformity with the Appellate Body's finding of WTO requirements, after taking note of the WTO case. ${ }^{56}$ The Federal Circuit took a similar position in overruling a lower court in an antidumping case against steel imports in 2003, citing a WTO decision as support even though noting that it was not bound by WTO jurisprudence. $^{57}$

Developing countries could also pool their resources through regional centers to assist them in defining trade priorities, coordinating negotiating strategies, building public-private networks, identifying trade barriers, and (potentially) providing legal support in WTO litigation. ${ }^{58}$ These regional centers could, for example, assist the Advisory Centre in WTO litigation. A Trade Law Center has been established in southern Africa and countries have explored creating one in Cairo, Egypt as well. ${ }^{59}$ States within regions face diverse challenges and their national interests can conflict, so that the development of regional centers faces significant challenges. ${ }^{60}$ Nonetheless, taking from the European example, countries increasingly realize the benefits to be gained from coordinating and pooling their resources. ${ }^{61}$ The pragmatic challenge of pooling resources at the regional level needs to be compared with the alternative of each

\footnotetext{
${ }^{55}$ Murray v Schooner Charming Betsy, 6 U.S. (2 Cranch) 64, 188 (1804) (Marshall C.J.) (known as the "Charming Betsy” rule).

${ }^{56}$ Turtle Island Restoration Network v. Donald Evans, 284 F.3d 1282, 1289-1290 (2002) (majority). When an environmental group challenged the revised U.S. State Department regulations, the U.S. government argued that the WTO ruling constituted "the law of nations," and that "an act of Congress ought never to be construed to violate the law of nations, if any other possible construction remains." See Turtle Island Restoration Network v. Donald Evans, 284 F.3d 1282, 1303 (2002) (dissent).

57 See Nippon Steel Corp. v United States, 337 F.3d 1373 (2003) and Allegheny Ludlum Corp. V United States, 367 F.3d 1339. Compare Appellate Body Report, United States - Countervailing Measures Concerning Certain Products from the European Communities, WT/DS212/AB/R, adopted Jan. 8, 2003.

${ }^{58}$ See e.g., Peter Drahos, "When the Weak Bargain with the Strong: Negotiations in the World Trade Organization," 8 International Negotiation 79-109 (2003).

${ }^{59}$ See Victor Mosoti, Does Africa Need the WTO Dispute Settlement System?, (ICTSD, Geneva) 1-28 (2003) available at http://www.ictsd.org/dlogue/2003-02-07/Mosoti.pdf. ”

${ }^{60}$ See, e.g., Paul-Henri Bischoff, "How Far, Where To? Regionalism, the Southern African Development Community and Decision-Making into the Millennium," in eds. Korwa Gombe \& Adar Rok Ajulu (2002), Globalization and Emerging Trends in African States' Foreign Policy-Making Process (Ashgate Pub.) p.299. ("However, the durability of national interests and intensification of transnational influences have not helped the SADC [Southern African Development Community] as a model of regional organization”).

${ }^{61}$ See e.g. Thomas Catan, "Mercosur seeks to build ties with Mexico,” Financial Times, July 6, 2002 at 2.
} 
developing country working on its own, in which case the trading powers can more easily play developing countries off of each other. ${ }^{62}$

Finally, the Advisory Centre and developing countries could work with academics that specialize in WTO law on a consultancy or pro bono basis. National and regional trade law advisory centers on trade law could affiliate with universities in developing countries, as has the Trade Law Center for Southern Africa (“TRALAC”) with the University of Stellenbosch. ${ }^{63}$ Some U.S. legal scholars have already worked on amicus curiae briefs in WTO cases, although they have generally sided with the great powers against developing country complainants, as in the U.S.-shrimp and EC-sardines cases. Many legal academics, however, might welcome the possibility of assisting developing countries on a WTO case. ${ }^{64}$ Not only would they provide a needed public service, but their own scholarship would benefit.

Most of the legal scholarship read in Geneva by WTO officials is written by U.S. and European scholars who are socialized to think of law from a U.S. or European perspective. As critical and constructivist scholars note, these scholars can exercise power in a diffuse, but important, way. ${ }^{65}$ Through their work, they can shape perceptions and the appreciation of alternatives. By working with developing countries on international trade cases, academics would better learn how the WTO process works in practice. They could write contextualized analyses of WTO jurisprudence that are more informed by a developing country perspective.

3. The Political Challenge: The Need for North-South NGO-Government Alliances. The third major challenge is that developing countries will often face extra-legal pressure from

\footnotetext{
${ }^{62}$ See e.g. Peter Drahos, "When the Weak Bargain with the Strong: Negotiations in the World Trade Organization," 8 International Negotiation 79-109 (2003). See also Gregory Shaffer and Yvonne Apea, "Institutional Choice in the GSP Case: Who Decides the Conditions for Trade Preferences: The Law and Politics of Rights,” Journal of World Trade (forthcoming 2005). Developing countries would of course have to monitor and develop trust that the secretariats of regional associations and the lead representatives in regional networks work effectively on their behalf.

${ }^{63}$ See Mosoti, Does Africa Need the WTO Dispute Settlement System?, supra note _.

${ }^{64}$ See e.g., Peter Drahos and Michael Blakeney, Rockefeller Report for Bellagio Conference (2002), cited in Reichman, "Managing the Challenge of a Globalized Intellectual Property Regime" (draft for the second Bellagio meeting on Intellectual Property and Development 2003) (on file) (proposing the formation of an "Academic Resource Group”).

${ }^{65}$ See e.g. Richard Ashley, "The Powers of Anarchy: Theory, Sovereignty and the Domestication of Global Life," reprinted in James der Derian, ed., International Theory: Critical Investigations 101 (1995) ("By contrast, my analysis looks to knowledgeable practices as productive relations of power. It looks to the way in which knowledgeable practices work in history to control ambiguity, privilege some interpretations over others, limit discourse, discipline conduct, and produce subjective agents and the institutional structures of their experience"); Ronen Palen, "The Constuctivist Underpinnings of the New International Political Economy, in Palen, ed, Global Political Economy: Contemporary Theories 219 (2000) ("knowledge, then, cannot be divorced from interest and the social position of the knower"); and Clarissa Rile Hayward, De-Facing Power (Cambridge University Press: 2000) (viewing power not in terms of "instruments powerful agents use...., but as social boundaries (such as laws, rules, norms, institutional arrangements, and social identities and exclusions) that constrain and enable action for all actors”).
} 
powerful countries, undermining the goal of objective trade dispute resolution through law. ${ }^{66}$ The powerful can exploit power imbalances and rhetorically rationalize their actions in non-powerbased terms. There may be little that a small developing country can do to counter threats to withdraw preferential tariff benefits or foreign aid-even food aid-were the country to challenge a trade measure. ${ }^{67}$ Such political tactics can undermine developing country faith in the efficacy of the legal system. The use of such tactics is not surprising. In domestic contractual disputes involving firms that exercise market power, these firms also benefit from the use of explicit and implicit threats. ${ }^{68}$ Developing countries can nonetheless better cope with them by adopting moreeffective strategies to attempt to constrain extra-legal pressures. As some recent cases demonstrate, developing countries can forge alliances with constituencies within the global powers. By harnessing domestic political pressure and legal expertise within the United States and Europe, developing countries can curtail, at least somewhat, great power political pressure and otherwise offset some of the resource imbalances that they face.

An example of a relatively successful north-south alliance is that between developing countries and northern-based non-governmental organizations (NGOs), such as Doctors Without Borders, concerning the recognition, scope, and enforcement of pharmaceutical patent rights. Together, they helped counter U.S. pressure on developing countries to enforce U.S. pharmaceutical company patents under a strict interpretation of the Agreement on Trade-Related Aspects of Intellectual Property Rights (“TRIPS Agreement”). First, the United States withdrew its threat of initiating a WTO claim against South Africa in response to pressure from AIDS activists on Vice President Gore's presidential campaign. ${ }^{69}$ Second, in June 2001, the Bush

${ }^{66}$ Guzman and Simmons find that statistical evidence concerning the selection of defendants suggests that developing country selection is more likely to be explained by capacity factors than power-based ones. See Andrew Guzman \& Beth Simmons, "Power Plays and Capacity Constraints: The Selection of Defendants in WTO Disputes,” Journal of Legal Studies (forthcoming 2005). Nonetheless, this author's interviews confirmed that smaller developing countries frequently face political constraints in initiating a WTO complaint.

${ }^{67}$ Confirmed in a number of interviews, including an interview with a former member of USTR (noting U.S. threat to high level officials in the capital of an African country that the U.S. might withdraw food aid were the country's Geneva representatives to press a WTO complaint). Similarly, a trade consultant noted how he was in the office of the trade minister of a country in Africa when the minister received a document from the U.S. embassy, which was the AGOA trade package. The document was thousands of pages. The trade minister received the document on a Friday and was to provide a definitive response by the following Wednesday. The consultant asked the minister what would be the consequences if the minister did not reply on Wednesday or said no. The minister responded that they were informed that they would lose funding to combat the AIDS epidemic. Telephone discussion, Nov. 29, 2004. See also Shaffer and Apea, GSP Case, supra note_.

${ }^{68}$ As Macaulay points out, “under bargaining, winning and losing is not necessarily related to 'legal' right or wrong; it may be related to the power and resources of the bargainers.” Stewart Macaulay, Lawrence Freidman \& John Stookey, The Legal System in Operation: Highlighting the Importance of Discretion, Bargaining, and "the Law," in LAW \& SOCIETY: READINGS ON THE SOCIAL STUDY OF LAW 160 (Macaulay, Friedman and Stookey, eds., 1995).

69 See Steven Meyers, South Africa and U.S. End Dispute Over Drugs, N.Y. TimES, Sept. 18, 1999, at A8 (stating that 300 protesters gathered in Philadelphia in June 1999 to chant “Gore’s greed kills!”); and Doug Ireland, “AIDS Drugs for Africa,” Nation, Oct. 4, 1999, at 5 (noting ACT UP demonstrators' chants of “Gore's greed kills” to pressure the administration to change its policies toward South Africa). Vice-President Gore was co-chairman of the U.S.-South Africa Bi-national Commission on pharmaceutical issues. Eventually, the U.S. Administration gave in. 
administration withdrew the United States' claim against Brazil's compulsory licensing provisions under Brazil's patent law in the context of widespread protest against the U.S. action from advocacy groups who maintained that the U.S. government was placing corporate interests above life-and-death medical concerns. ${ }^{70}$ This NGO pressure was complemented by prodding from international health organizations. ${ }^{71}$ Third, USTR Robert Zoellick abandoned the U.S. pharmaceutical industry with little consultation in agreeing to the "Declaration on the TRIPS Agreement and Public Health" at Doha. ${ }^{72}$ The United States again backed down just before the September 2003 Cancun WTO ministerial meeting concerning the right of developing countries without manufacturing capacity to issue compulsory licenses for the importation of generic drugs. $^{73}$ Even though northern activists and developing countries would like to go further in modifying and officially interpreting the TRIPS Agreement, they have helped to counter aggressive pressure and shifted the terms of debate over the protection of pharmaceutical patents.

Similarly, developing countries can work with northern consumer groups in bringing WTO claims. In the case EC-Trade Description for Sardines, the UK Consumers' Association, the largest consumers association in Europe and the second largest in the world, worked with a UK law firm, Clyde \& Co, on a pro bono basis to prepare an amicus curiae brief in support of Peru's submissions to the WTO panel. In this case, Peru challenged an EC regulation that would

See Gary Yerkey, "President Orders Easing of IPR Policy For Sub-Saharan Africa to Help Fight AIDS,” 17 International Trade Reporter (BNA) 792 (May 18, 2000).

70 See, e.g., "U.S., Brazil End WTO Case on Patents, Split on Bilateral Process," 19 Inside U.S. Trade 1, 2 (June 29, 2001) ("Informed sources said the U.S. backpedaling from the WTO panel, which it had requested in February, reflected an unwillingness on the part of U.S. Trade Representative Robert Zoellick to give opponents of trade liberalization a red-hot issue that appeared to give credence to the idea of the WTO interfering with poor countries' health policies."). Doctors Without Borders declared that Brazil's patent policy was key to the success of the Brazil's strategy to offer universal access to HIV/AIDS medication in Brazil. Brazil's health program includes free distribution of antiretroviral drugs produced in Brazil. This program has allegedly reduced AIDS deaths by 50 percent since it was introduced and saved the government an estimated \$422 million in hospitalization and medical care costs. See Daniel Pruzin, "US Responds to Criticisms of Brazilian Patent Law Complaint," 18 International Trade Reporter (BNA) 238 (February 8, 2001). Oxfam, a British NGO, backed Brazil’s efforts, maintaining that the U.S. complaint was an assault on public health. See Drug Companies vs. Brazil: The Threat to Public Health, available at http://www.oxfam.org.uk/policy/papers/brazilctc/ctcbraz.htm.

71 For example, 52 countries of a 53 member United Nations Commission endorsed Brazil's AIDS policy and backed a resolution sponsored by Brazil that called on all states to promote access to AIDS drugs. See UN Rights Body Backs Brazil on AIDS Drugs, News24.COM, Apr. 24, 2001, available at http://www.news24.com/contentDisplay/level4Article/0,1113,2-1134_1014970.00.html.

72 E-mail from Washington insider (June 27, 2002) (concerning the lack of consultation). See also Gary Yerkey \& Daniel Pruzin, "Agreement on TRIPS/Public Health Reached at WTO Ministerial in Doha," 18 International Trade Reporter (BNA) 1817 (Nov. 15, 2001) (noting that "representatives with the pharmaceutical industry were less than enthusiastic," and a Swiss officials, also representing pharmaceutical interests, "expressed fury at being excluded"). See generally WTO Secretariat, Declaration on the TRIPS Agreement and Public Health, WT/MIN(01)/DEC/2 (Nov. 20, 2001) (recognizing a number of "flexibilities" in the TRIPS Agreement).

73 See Council for TRIPS, Implementation of paragraph 6 of the Doha Declaration on the TRIPS Agreement and Public Health, WT/L/540 (August 30, 2003). 
not permit Peruvian fish to be sold as "sardines" within the EC, even though they could be sold throughout the world as sardines in accordance with an international standard agreed under the auspices of the Codex Alimentarius Commission. ${ }^{74}$ The ten-page brief of the Consumers' Association addressed how the EC regulation "clearly acts against the economic and information interests of Europe's consumers" and constitutes "base protectionism in favour of a particular industry within the EU," the Spanish fishing industry. Thanks to the Consumers' Association and its law firm, Peru and the Advisory Centre on WTO Law received free legal research and counsel on such issues as the history and application of the EC regulations and the Codex standard-setting procedures,.

The Advisory Centre attached the association's amicus brief to Peru's legal submission and quoted it with approval. ${ }^{75}$ The brief had an impact on the WTO panel, which cited it concerning European consumer views. ${ }^{76}$ When the EC challenged the panel's use of the Consumers' Association brief during interim review, the panel confirmed that it justifiably considered the brief "in determining whether the European consumers associate the term 'sardines' exclusively with Sardina pilchardus," the fish variety swimming in European waters. The panel then found that European consumers did not associate sardines exclusively with this variety, in contradiction of the EC's position. There was thus no reason that the Peruvian species could not be sold as sardines in the EC market. The Appellate Body upheld the panel's central findings in favor of Peru.

The Advisory Centre on WTO Law can assist in the forging of these north-south NGOgovernment alliances. Since the Centre's lawyers are repeat players in WTO litigation, and since they are based in Geneva, the home of the WTO, they more easily can develop relations with northern groups to provide assistance in specific trade matters. ${ }^{77}$ The Advisory Centre's general policy is to post its legal submissions on the Centre's web site, facilitating interaction with

\footnotetext{
74 See Shaffer \& Mosoti, EC-Sardines, supra note _, at 15.

75 For example, Peru referred to the brief in its submission to the panel to point out how a "wide range of tuna or bonito species can be marketed in the Community under a common standards regime," rendering it "difficult to understand why sardines should be marked out for a particularly restrictive regulatory regime." Second Submission of Peru, EC-Trade Description of Sardines, WT/DS231 (Jan. 11, 2002), para. 71, available at http://www.acwl.ch/pdf/SecondSubmitPeru.pdf .

76 See Report of the Panel, EC-Trade Description of Sardines, WT/DS231/R (May 29, 2002), paras. 6.13-.15, 7.131-.132. The panel refused to review letters from other EC consumer organizations that the EC submitted during the interim review stage, on the grounds that such stage was too late in the process to introduce new evidence. See id. at 6.16 .

77 Largely serendipitously, the Advisory Centre's director, Mr Roessler, met a senior member of the UK Consumers' Association at a conference in London concerning international trade law. Following the conference, the Consumers' Association agreed to support Peru's submissions in the EC-Sardines case. Telephone interview with member of the UK Consumer's Association (Sept. 10, 2002).
} 
NGOs, lawyers, academics, and others. ${ }^{78}$ Some developing country NGOs, such as Consumer Unity \& Trust Society (CUTS) based in India, are also attempting to help forge north-south alliances. ${ }^{79}$ Oxfam, for example, has been a major supporter of Brazil's challenges to U.S. and European cotton and sugar subsidies. ${ }^{80}$ As happened for Peru in the sardines case, these alliances can help undermine the opposing party's factual and legal positions. By shaping the normative and political contexts in which legal challenges occur, they can also countervail industry pressure on executive departments in larger developed countries to take aggressive stances toward developing countries in the first place.

International negotiations involve a two-level game in which national constituencies compete in the formation of national positions and those national positions are then advanced in international negotiations. ${ }^{81}$ If developing countries cannot neutralize the clout of U.S. and European firms in the formation of U.S. and European positions, then developing countries will more likely face the full brunt of U.S. and European pressure in regards to pharmaceutical patents and other WTO claims. In a world of asymmetric power, developing countries enhance the prospects of their success if other U.S. and European constituencies can offset industry pressure on U.S. and European trade authorities. Developing countries need to work with these constituencies to alter the domestic political playing fields of the other side.

\section{Conclusion.}

If developing countries are to participate meaningfully in the WTO dispute settlement system, they will need to continue to increase institutional capacity and coordination of trade policy at multiple levels, from the national to the regional to the global. They will need, in particular, to develop their own coordinative mechanisms to include private sector and civil society representatives. Capacity building endeavors generally will be most sustainable if they permeate broadly throughout institutions and societies. ${ }^{82}$

78 Interview with member of the Advisory Centre on WTO law, in Geneva, Switz. (June 18, 2002). The client member, however, makes the ultimate decision. See ACWL, Policy on Publication of Submissions during WTO Dispute Settlement Proceedings, at http://www.acwl.ch/e/dispute/dispute_e.aspx (visited May 10, 2005).

79 Confirmed in e-mail from CUTS representative, Sept. 19, 2002.

${ }^{80}$ See e.g., Oxfam, “Busted: World Trade Watchdog Declares EU and US Farm Subsidies Illegal” (Sept. 8, 2004) available at http://www.maketradefair.com/en/index.php?file=cotton_pr03.htm.

81 See e.g., Robert Putman, “Diplomacy and Domestic Politics: The Logic of Two-level Games,” International Organization 427 (1988); and Double-Edged Diplomacy: International Bargaining and Domestic Politics (Peter B. Evans et al., eds., 1993).

82 If the focus of capacity building remains on individual capacity instead of larger societal and institutional capacity, then countries could simply be training individuals whose objectives and career paths are unpredictable. See Gregory Shaffer, “Can WTO Technical Assistance and Capacity Building Serve Developing Countries?” supra note_. Michel Kostecki found in regards to WTO “capacity building” programs, "some of the civil servants attending training events were not primarily involved in trade policy-making. In addition, course participants may move on to jobs that are not trade-related, or quit the government for the private sector." See Michel Kostecki, “Technical Assistance Services in Trade-Policy,” ICTSD Resource Paper No. 2 (Nov. 2001), at 20. 
If developing countries are to deploy WTO law to their advantage, they will need to maintain routine on-going procedures for gathering, processing and prioritizing information from foreign embassies, the private sector, and international trade consultants regarding foreign trade barriers. By working more consistently with the private sector, developing country officials can foster the development of reflexes in firms and trade associations to view the WTO as an opportunity to ensure market access, thereby more effectively using the WTO system to their advantage. Brazil has gone a long way toward institutionalizing this coordination in WTO dispute settlement, and Brazil has become a much more active and successful user of the system as a result. ${ }^{83}$ Building requisite developing country public-private networks will take time. Yet it is an essential task if the WTO dispute settlement system is to work for them.

Many developing countries are learning to use the WTO dispute settlement system more effectively. The Advisory Centre, with its growing experience and knowledge of the system, represents a significant advance. Private law firms are likewise dedicating more resources to WTO dispute settlement into which some developing countries can tap. With time, developing countries should be able to gain a greater strategic sense of how to use the dispute settlement system and to work with broader networks of public and private actors to advance their concerns. They will always be at a significant disadvantage because of material and informational resource constraints and political factors that they cannot control. Yet the WTO legal system can also offer opportunities for them.

Since developing countries face different contexts, there is no single strategy that fits all of them. Exporting legal strategies across cultures regardless of context has never worked. ${ }^{84}$ Each country will need to determine how best to adapt the strategies that this paper explores in light of its particular circumstances. Many countries already have adopted many of them to a varying extent. The paper's central purpose is to highlight options and provoke imaginative debate and experimentation with strategies that developing countries and their constituencies may adopt to better defend themselves in the international trading system.

\footnotetext{
${ }^{83}$ Brazil brought twenty-two complaints before the WTO dispute settlement system during the system's first ten years, more than any other developing country. Yet Brazil had litigated no case except where a private company or trade association had hired and worked with a law firm to prepare the legal submissions. Interview with officials from the Brazilian Ministry of Foreign Affairs, Brasilia, Brazil, April 19, 2004.

${ }^{84}$ See e.g., David Trubek \& Marc Galanter, Scholars in Self-Estrangement: Some Reflections on the Crisis in Law and Development Studies in the United States, 1974 WIS. L. REV. 1062.
} 